Article

\title{
Potential for Conservation Agriculture in the Dry Marginal Zone of Central Syria: A Preliminary Assessment
}

\author{
Baqir Lalani ${ }^{1, *(\mathbb{D})}$, Bassil Aleter ${ }^{2}$, Shinan N. Kassam ${ }^{3}{ }^{\mathbb{D}}$, Amyn Bapoo ${ }^{4}$ and Amir Kassam ${ }^{5}$ \\ 1 Natural Resources Institute, University of Greenwich, Medway Campus, Central Avenue, \\ Chatham Maritime, Kent ME4 4TB, UK \\ 2 United Nations Office for the Coordination of Humanitarian Affairs (UNOCHA), West Villas, Mazzeh, \\ Gazawi Str. No.8, P.O. Box 2317 Damascus, Syria; baleter@gmail.com \\ 3 Caritas Switzerland, Adligenswilerstrasse15, P.O. Box CH-6002 Lucerne, Switzerland; skassam@caritas.ch \\ 4 Aga Khan Foundation, 1-3 Avenue de la Paix, 1202 Geneva, Switzerland; amyntz@gmail.com \\ 5 School of Agriculture, Policy and Development, University of Reading, Whiteknights, P.O. Box 217, \\ RG6 6AH Reading, UK; amirkassam786@googlemail.com \\ * Correspondence: B.Lalani@greenwich.ac.uk; Tel.: +44-(0)-1634-883571; Fax: +44-(0)-1634-883706
}

Received: 9 December 2017; Accepted: 1 February 2018; Published: 14 February 2018

\begin{abstract}
This paper reports on early soil related outcomes from conservation agriculture (CA) benchmark sites located within the marginal rainfed environment of agro-ecological zone 4 (annual rainfall: $200-250 \mathrm{~mm}$ ) in pre-conflict central Syria. The outcomes reported are specifically those that relate to beneficial soil quality and water retention attributes relative to conventional tillage-based soil management practices applied to the fodder barley-livestock system, the dominant system in the zone. On-farm operational research was established to examine the impact of a barley (Hordeum vulgare) and vetch (Vicia sativa) rotation intercropped with atriplex (Atriplex halimus) and salsola (Salsola collina), under CA and conventional tillage agriculture, on the soil quality parameters and crop productivity. Preliminary results showed that CA had a positive effect on the soil quality parameters and crop performance. The soil moisture and hydraulic conductivity were higher under CA $(p<0.05)$, combined with improved productivity (grain and above-ground biomass) under specific crop mixes. The results suggest that despite the marginal nature of the zone, the use of CA is a viable option for the future of farmers' livelihoods within similar localities and agro-climates, given the benefits for soil moisture and grain and straw productivity. In addition, it is likely to positively impact those in marginal environments where both pastoralism and agro-pastoralism production systems co-exist and compete for crop biomass as a main source of livestock feed. The increase in grain and straw yields vis-à-vis improvements in biophysical parameters in the CA system relative to tillage agriculture does suggest, however, that the competition with livestock for biomass is likely to reduce over time, and farmers would be able to return increased levels of straw (as stubble and residue) as mulch, given improved biomass yields.
\end{abstract}

Keywords: conservation agriculture; crop-livestock interactions; Syria; soil health; agricultural innovation

\section{Introduction}

Conservation agriculture (CA) has been promoted as a land use management practice that is better able to achieve a desired objective of sustainable production intensification [1]. CA systems comprise the implementation of three interlinked principles: (i) no or minimum mechanical soil disturbance through no-till seeding and weeding; (ii) the maintenance of soil mulch cover with crop residues, stubbles and cover crops; (iii) cropping system diversification through rotations and/or associations 
involving annuals and perennials, including legume crops [1]. A ground cover of $30 \%$ or more is a requirement, because this reduces soil erosion substantially and provides a substrate to soil biota to build and sustain soil health and functions, as well as increases the soil organic matter content, which improves the structure, infiltration and moisture retention capacity. Provided that the $\mathrm{C} / \mathrm{N}$ ratio in the substrate is conducive, microbes will not bother with biomass with high $\mathrm{C}$ and very low $\mathrm{N}$, as is the case with barley (Hordeum vulgare) straw.

Transitioning from a conventional tillage-based production system to a CA system requires time for the transformation to occur, in which the three core CA practices are promoted along with other good agricultural practices, including those of integrated crop, soil, nutrient, water, pest and energy management. It is thus clear that the feasibility of adopting CA or implementing CA practices will depend on a range of biophysical, economic, socio-cultural, management and developmental issues related to the prevailing agricultural environment. Consequently, while CA comprises three principles, at the practical level of the CA adoption process, there cannot be a "one-size-fits-all" approach when it comes to how CA is introduced, practiced and evolved in a particular biophysical environment and socio-economic rural setting. This equally applies to how CA adoption can be scaled and organized to harness territorial level benefits for rural communities and the society at large. CA principles apply to production systems in all land-based agro-ecologies, including sown fodder crop-livestock systems or sown pasture-livestock systems of various kinds. In some respects, these are relatively simpler systems to transition to-from a conventional tillage-based production system to a CA system-because they lend themselves to no-till seeding using a diverse mixture of species. However, what is required in transforming such systems from their conventional versions to CA systems is the need to manage livestock differently, such that grazing management is based on a rotational system and thus the minimum necessary ground cover is maintained to build soil health, control erosion and increase biomass production.

Research findings from marginal areas with Mediterranean environments in a number of countries indicate that grain and biomass yields and factor productivities have improved through the adoption of CA, in addition to improvements in soil quality [2-5]. Additionally, and of particular relevance to dryland areas, a number of other likely benefits have been reported. These include, even within dryer months of the year, improved rates of water infiltration, appreciable reduction in run-off losses and increased replenishment of groundwater $[3,4,6]$. The spread of CA cropland systems worldwide has been occurring at a rate of some 10 million hectares per year since 2009 , with some $50 \%$ of the area located in low-income countries, including in the Mediterranean environments [3,7]. The broad adoption of CA has been less than desired within the West and Central Asia region, particularly so within the dryland Mediterranean environments. However, the situation has begun to change in recent years in countries such as Kazakhstan, Uzbekistan, Kyrgyzstan, Tajikistan, Armenia, Azerbaijan, Iran, Turkey, Lebanon, Jordan, Iraq, Syria and Pakistan, where CA adoption has been reported [3,7-10].

Within dryland environments, as in many other parts of the world, intensive tillage, bare and exposed soils and mono-cropping continues to contribute to land degradation and to low crop (including fodder and pasture) and total land productivity, thereby inhibiting the prospects for enhanced sustainable agricultural production within these regions (within the CGIAR research system (www.cgiar.org), drylands are defined on the basis of an aridity index. Consistent with that employed by the United Nations Convention to Combat Desertification (UNCCD) as well as the United Nations Food and Agriculture Organization (FAO), drylands are defined as regions having an aridity index of 0.65 or less (http:/ / www.eatlasdcl.cgiar.org/Docs/WorkingDefinitionOfDrylands.pdf). Estimates suggest that close to 2.1 billion people call drylands their home) [11,12]. Options for uncovering contextually relevant shifts in land use management paradigms with improved environmental, social and economic underpinnings have therefore been of key concern to institutions of agricultural research-both national and international. In Syria, the benefits of CA for soil moisture and grain and biomass yields have recently been uncovered [13], but in a number of cases, these have been in a piecemeal fashion in terms of testing the application of the three interlinked core components of 
CA. More generally, meta-analyses and reviews, such as those by [14-18], while highlighting some of the challenges related to CA adoption, show clear moisture-related benefits to crop growth and productivity in CA systems, particularly in semi-arid areas.

Two aspects are important in a persistent argument for not favoring the maintenance of minimum ground mulch cover through the utilization of crop stubbles and straw residues in marginal environments exhibiting strong crop-livestock interactions. The first relates to conventional wisdom, which frowns on direct grazing, given concerns over the retention of animal droppings, which has implications for weed growth (on the basis of discussions with staff at the International Center for Agricultural Research in the Dry Areas (ICARDA) and author discussions in the field). While the concept of managed rotational grazing is now well recognized for its potential to retain stubble and crop residue and, if undertaken with efficacy, a certain amount of residue retention as ground cover, it is argued that animal droppings are likely to contain weed seeds, which would lead to competition with the main cereal crop. This argument is not as important when the crop concerned (i.e., barley) is for fodder, as is the case in zone 4 in Syria.

The district is divided into four standard agro-ecological zones, which span the entire republic. Instituted more than half a century ago, these zones have been (for reasons not entirely known) immutable to change, despite significant variation in annual and seasonal rainfall patterns and a general downward trend in rainfall, the latter resulting in sustained periods of drought and increasing instances of winter frost. Zone 2, located to the east, is relatively the wettest area, with an average annual rainfall of more than $300 \mathrm{~mm}$. In contrast, zone 3 is slightly drier, with a typical average of 250 to $300 \mathrm{~mm}$ of rainfall per year. Zone 4 is a marginal area receiving on average between 200 and $250 \mathrm{~mm}$ of annual rainfall and bordering zone 5-the Badia (reasonably suitable for nomadic herding) and steppe zone, which on average receives less than $200 \mathrm{~mm}$ of rainfall annually. Zones 2 and 3 are characterized by mixed crop-livestock production systems, and zone 4 exhibits the heaviest crop-livestock interaction. The incentive to produce barley, the primary cereal crop grown within the district, varies by zone. Grain production is a primary economic incentive within the relatively wetter zones 2 and 3, while fodder is of primary interest and incentive in zone 4. Prior to 2004, government support in the form of input subsidies, together with a guaranteed buy-back scheme (price and quantity), provided significant economic incentives in the production of grain barley as well as a number of other key national strategic crops such as wheat, tobacco and certain food legumes in particular. Since this time, and after the removal of regulatory support, the production of grain and fodder barley has largely been driven by an economic need to support a fairly significant stock of small ruminants, specifically sheep-and particularly within zone 4 and the vast rangelands of zone 5 where a large portion of national small ruminant livestock holdings are located.

Thus, a second and more compelling argument is a concern over competition for fodder biomass (including straw during the dry season) for feeding livestock-in lieu of retaining a portion for maintaining minimum ground cover, given that little straw is left as ground cover as a result of the low production potential of the barley production zone. Contesting this argument, recent research work in Syria [8] has shown favorable impacts of a no-till system with respect to the potential for biomass retention for ground cover as well as for soil properties and moisture retention.

Other studies have further highlighted the beneficial aspects of straw biomass retention for the surface during the dry season when the biomass is not needed for feeding livestock [19]. Additionally, fodder yield improvements have been demonstrated [20] from barley and vetch (Vicia sativa) intercrops in dryland Syria, with reduced tillage and barley straw used as surface ground cover. More recently, significantly higher grain and biomass yields and gross margins have been documented [21] for a variety of crops, including barley under a no-till system, when compared to the conventional tillage-based system in Syria in zone 2. Despite the fact that zone 2 has a relatively higher production potential compared to zone 4, implicitly included is an understanding that above-ground crop biomass (stubble base with root tops, and cut straws and leaves) yields are also likely to increase under a no-till system, relative to the conventional tillage-based system. 
Taken together, there is an argument that, in the early phase of transforming from the tillage-based production system to the adoption of CA system practices, a constraint for crop biomass in the use as soil cover is a limiting factor. However, it is argued this this constraint is released over time with the adoption of CA practices, leading to an increase in the biomass yield in the case of zone 4 and in grain and biomass in the case of zones 2 and 3, with the introduction of cover crops in the cropping system contributing additional biomass. Further, with no-till, plant-base or stubble with attached roots, this will also contribute to ground cover and soil health.

The developmental question, therefore, is how to reduce this biomass constraint and overcome it over time in zone 4, where the crop-livestock farming system relies on growing fodder crops of barley, vetch, fodder shrubs and natural rangeland vegetation as the main source of livestock feed.

\section{Study Objectives and Region}

\subsection{Study Objectives}

We believe this to be the first CA-based applied research study carried out, albeit preliminarily, within the marginal rainfed environment of the agro-ecological zone 4 in Syria (Figure 1), which borders the vast rangelands within the republic, with an aim to investigate the potential benefits of a CA production system relative to the conventional tillage-base production system (for this manuscript, conventional tillage and traditional agriculture is used interchangeably to denote the treatment that utilizes ploughing).

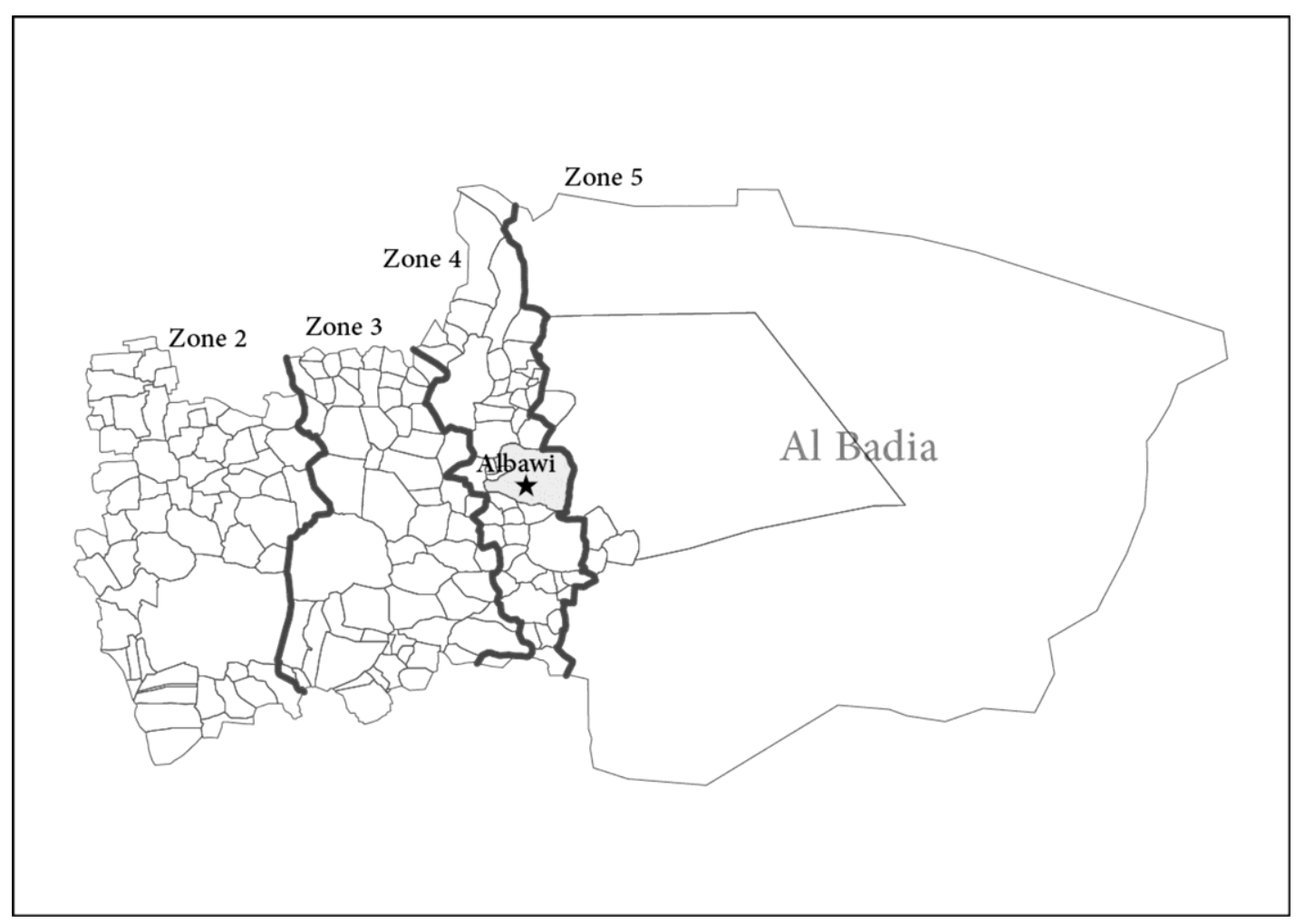

Figure 1. Agro-ecological zones in Salamieh District, Syria.

The study comprises an on-farm demonstration of CA and aims to assess its validity within this marginal environment with strong crop-livestock interactions and through an analysis of barley and vetch and ervilia (Vicia ervilia) and barley rotations intercropped with the fodder shrubs atriplex (Atriplex halimus) and salsola (Salsola collina), under both a CA system and the conventional tillage system. Previous research conducted in Ghrerife, Syria (mean annual rainfall of $267 \mathrm{~mm}$, i.e., in zone 2) 
has highlighted the benefits (under conventional tillage) of barley intercropped with atriplex in providing sources of additional feed as well as in reducing the likelihood of soil erosion from wind [22]. This form of alley cropping was found to be particularly useful as a method to buffer the total feed output against seasonal fluctuations brought about by variability in rainfall.

In addition to an assessment of the early impact on soil quality parameters and crop productivity, the study also examines the impact of each treatment on net farm incomes. It must be mentioned at the outset that the purpose of this study was not to carry out an on-station-type trial, but rather to engage in on-farm operational research, which actively engaged farmers within the surrounding areas through demonstration, consultation, dialogue, and training. On-farm operational research reflects a two-way dialogue in which farmers in the field are active partners in the investigation and are able to assess the impact of different options in the "field" [23,24]. It has also been argued [2] that without farmer engagement and appropriate commitment from farmers to test CA system practices, the integration of such practices into production systems and the rapid adoption of CA by farmers, including the required transformational changes for CA system development, are unlikely to occur. This sentiment is very much in line with recent attention paid to the efficacy in innovation systems, away from a historical concentration on linear models for technology transfer and dissemination and into more participatory multi-stakeholder processes for agricultural innovation $[25,26]$.

In keeping with this notion of participatory innovation, we further argue that in addition to sustainable production intensification, the role of CA in supporting resilience (productivity-environmental, social and economic) within fragile production systems is equally relevant, but is not (generally) promoted in dissemination and demonstration strategies by either developmental agencies or national centers of agricultural research. This is particularly true in terms of the potential ability for CA in production areas, where there are interactions between pastoral and agro-pastoral livelihood systems, to reduce conflict in periods of sustained drought and fluctuations in production volumes of cereal and fodder crops.

\subsection{Study Region}

The district of Salamieh is situated in central Syria and covers approximately $5000 \mathrm{~km}^{2}$, with an estimated population of 241,000 (civil statistics in Syria are guarded with much sensitivity, and particularly so with respect to the registration of individuals.). A significant portion of cultivable land is rainfed (100,174 ha), with only a small portion (9225 ha or 9\%) under irrigation [27]. Conventional wisdom, supported by anecdotal evidence, suggests that over years of sustained drought, farmers (particularly mobile and semi-settled farmers) will often liquidate their livestock holdings, and sometimes even abandon them in times of severe market depression, as they are unable to meet necessary feed requirements. Reducing the feed gap through sustainable improvements in fodder biomass production is therefore of significant importance to livelihoods and security in marginal zones, and particularly so when poverty is prevalent and linkages to markets are either weak or not inclusive. While farmers in marginal areas may be concerned with good soil health, higher levels of soil organic matter and all of the beneficial environmental outcomes that accrue from shifting land use paradigms, these outcomes in Syria at least for now are largely situated within the ambit of some research scientists.

In general, it is now well accepted that the initial appeal for farmers to engage in the CA adoption and transformation process is in the form of reduced costs due to no-till seeding [21]. However, predictability in providing a stand of fodder barley for direct grazing may be more of an incentive to farmers in marginal zones, where strong crop-livestock interactions exist, where crop-mix choices are limited by the extent of the access to groundwater and are exacerbated by regulatory restrictions on cropping. The implications of residing within "static" agro-ecological cropping zones are that historic edicts on cropping patterns are fixed, and, when desired, deviating farmers can be punished under the extent of the law. Within zone 4, cropping is restricted to the rainfed production of fodder crops, and the planting of trees, particularly olives, is prohibited by the regulatory code. National statistics 
would suggest that regulations are being adhered to with respect to prohibitions on the planting of trees, yet anyone familiar with the landscape of central Syria is cognizant of what is stated in official statistics and what exists on the ground. While not as dense or lucrative as in other, wetter zones with relatively well-endowed access to groundwater resources, olive production provides a valuable source of revenue to supplement income streams from the production of dairy products and in support of investments in livestock holdings, which are a form of capital asset and security.

The production of cereal-based fodder cropping, therefore, provides an anchoring of financial input, which supports the livelihood systems for both resident farmers and nomadic farmers, who rent out land for grazing in order to support livestock holding. Supporting resilience and improving the productivity of cereal- and fodder-based crops and shrubs through a shift away from tillage-based production systems is, therefore, a priority area of focus within the broader strategy of research for development. This is not simply an agenda for cost savings and productivity enhancement but is equally important for reversing agricultural land degradation, rehabilitating abandoned agricultural land, and for social and environmental stability, particularly so since the armed uprisings within Syria, and the region more generally, in 2011.

\section{Materials and Methods}

\subsection{Trial Demonstration Plots}

On-farm trial demonstration plots, initiated in October 2010 (Figure 2), were managed by the Aga Khan Foundation (http:/ /www.akdn.org/our-agencies/aga-khan-foundation), an international development organization, in collaboration with the farmer, a private landowner. The plots were located in the Al-Bawi village within zone 4 but were on the edge of the rangelands within zone 5 .

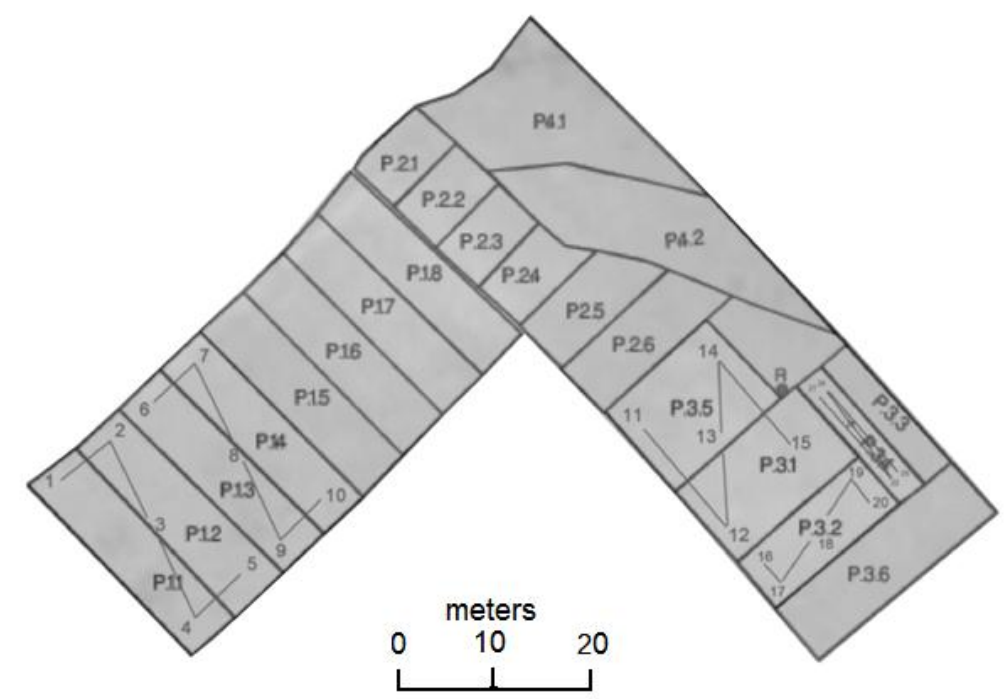

Figure 2. Schematic of trial plots initiated in October 2010 by Aga Khan Foundation. Depicts all of the conservation agriculture (CA) benchmark sites (for different crops/treatments, etc.) set up by the Aga Khan Foundation in Al-Bawi. For the purpose of this study, we only report on outcomes from plots P.11-P.14.

The on-farm trial demonstration of two treatments (CA vs TA-tillage agriculture) were unreplicated and aimed to assess the impact of different seeding options incorporating barley and ervilia vetch intercropped with atriplex and salsola on plots under CA and TA (we denote TA as a short form of "traditional" or conventional agricultural land use practices, which utilize motorized tillage-based practices). Plots P.11 (CA) and P.14 (TA) were seeded with barley (intercropped with artriplex and salsola) in 2010/2011 followed by a mixture (30\% barley and $70 \%$ ervilia) in the 
subsequent season, 2011/2012. Plots P.12 (CA) and P.13 (TA) were seeded with ervilia (intercropped with fodder shrubs atriplex and salsola) in the 2010/2011 season, followed by barley in 2011/2012 (see Table 1 for the description of treatments).

Applications of fertilizer and seeding rates were kept constant between the two treatments. The seeding rates were $100 \mathrm{~kg} \mathrm{ha}^{-1}$ for barley and $150 \mathrm{~kg} \mathrm{ha}^{-1}$ for ervilia vetch. All plots received phosphorus and nitrogen triple superphosphate (TSP) at seeding time $\left(50 \mathrm{~kg} \mathrm{ha}^{-1}\right)$ and urea $\left(50 \mathrm{~kg} \mathrm{ha}^{-1}\right)$ after germination. No herbicides were applied. Atriplex and salsola shrubs were also intercropped in all plots, but showed little growth in the 2 years under study; therefore it was not possible to record their biomass yields. For the CA plots, a minimum of $30 \%$ ground cover with crop residue (barley straw and leaf biomass) was maintained. All plots within the on-farm benchmark site were sown with a no-till tine seeder developed by ICARDA at its research station in Aleppo.

Table 1. Treatment description for on-farm trial demonstration.

\begin{tabular}{cccc}
\hline Plot ID & Main Treatment & Year & Sub-Treatment \\
\hline P.12 & Conservation agriculture (CA) & $2010 / 2011$ & Ervilia intercropped with atriplex and salsola \\
P.12 & CA & $2011 / 2012$ & Barley intercropped with atriplex and salsola \\
P.13 & Traditional/conventional agriculture (TA) & $2010 / 2011$ & Ervilia intercropped with atriplex and salsola \\
P.13 & TA & $2011 / 2012$ & Barley intercropped with atriplex and salsola \\
P.11 & CA & $2010 / 2011$ & Barley intercropped with artriplex and salsola \\
P 11 & CA & $2011 / 2012$ & Barley (30\%) and ervilia (70\%) \\
P.14 & TA & $2010 / 2011$ & Barley intercropped with artriplex and salsola \\
P.14 & TA & $2011 / 2012$ & Barley (30\%) and ervilia (70\%) \\
\hline
\end{tabular}

\subsection{Soil Sampling}

Undisturbed and disturbed soil samples were taken from both CA (P.11 and P.13) and TA (P.12 and P.14) plots at 0-20 $\mathrm{cm}$ depths in February 2011. Five cores per plot were taken in a zig-zag pattern from each plot (see Figure 2) were and analyzed at the ICARDA laboratory based in pre-conflict Aleppo. Watermark sensors (Gypsum block) were placed on both plots (P.12 and P.13) for the 2011-2012 growing season. In order to convert pressure head data into moisture equivalents, the soil moisture-pressure head curve was used; established with the van Genuchten equation [28] through employment of the Rosetta neural network calculation (1999; U.S. Soil Salinity Laboratory) using values for bulk density and texture. Similarly, Hydraulic conductivity (cm/day) was predicted using the values for bulk density and soil texture using the neural network format (Rosetta Software).

\subsection{Rainfall}

Rainfall (precipitation) data from MAAR (Agricultural Statistics, Ministry of Agriculture and Agrarian Reform) were used to give an idea of the recent trends in rainfall during the growing seasons. Where comparisons of soil moisture between CA and TA during peak rainfall periods are presented, these are based on data from a digital solar weather station (Davis Instruments, Vantage Pro2 Weather Station, UK) that has a digital rainfall gauge included to measure precipitation. Hourly readings were taken and the analysis for both soil moisture and hydraulic conductivity are based on a total of 6713 readings per observation.

\subsection{Grain Yield and Biomass}

All plots sizes were 2.5 dunums ( 1 dunum $=0.1$ ha). To estimate the yield and biomass, five replicate samples of $1 \mathrm{~m}$ by $1 \mathrm{~m}$ square quadrants were harvested from each plot at the end of the crop growing period. After drying, the samples were weighed and recorded and the mean weight of the five replicates was used to calculate the grain yield and biomass yield (above-ground biomass). 


\subsection{Financial Returns}

Partial farm budgets were used to calculate the financial returns of the various treatments. These did not include labor or harvesting and transport costs and only relate to the treatments used, that is, the cost of fertilizer and the tractor service for ploughing and seeding for conventional seeding and for no-till seeding. From the perspective of the discipline of economics, a lack of inclusion of these costs would raise questions. Two reasons support our argument for excluding these costs. The first is that the trial demonstrations were undertaken in a period of initial civil unrest and markets for all inputs had been significantly affected, particularly for labor and material inputs (fuel, machinery, etc.). Secondly, as we were looking primarily at improvements in productivity and returns for farmer demonstration together with beneficial environmental outcomes for research and public good interest, the collection of these data was not directly relevant for the immediate purpose at hand.

Providing information to farmers on the saving of material inputs was in line with conventional wisdom that out of pocket savings in expenses is an initial motive for engaging in the process of $\mathrm{CA}$ adoption and establishment. Labor within these marginal areas is predominantly household-based, and farmers would have likely made quick calculations on the impact of a shift in land use management practices in terms of their household labor utilization. For ease of comparison, input and commodity prices are based on 2011 prices prior to the civil unrest in Syria. The currency conversion used was 50 Syrian pounds per US dollar (USD). Those wishing to undertake a comparative analysis of returns with work conducted in zone 2 [21] would find similarity in this respect. For the CA plots in the study, all of the crop biomass (residue) was retained as surface mulch and was valued at the going market rates for biomass (straw) in feeding livestock.

\subsection{Statistical Analysis}

Statistical analysis was conducted using the Statistical Package for Social Scientists (SPSS). Means were compared using the Student's $t$-test. The results were considered statistically significant at $p<0.05$.

\section{Results and Discussion}

\subsection{Rainfall}

The rainfalls over the 2010/2011 and 2011/2012 cropping seasons were 159.0 and $197.5 \mathrm{~mm}$, respectively (Figure 3). While the rainfall in 2010/2011 was close to the average, the rainfall during 2011/2012 was higher than the average cropping season rainfall of $154.6 \mathrm{~mm}$ between 2005 and 2013 (Figure 3). While beneficial in terms of trial demonstrations to farmers, this higher-than-average rate of rainfall during 2011/2012 should be factored into an analysis of early results obtained.

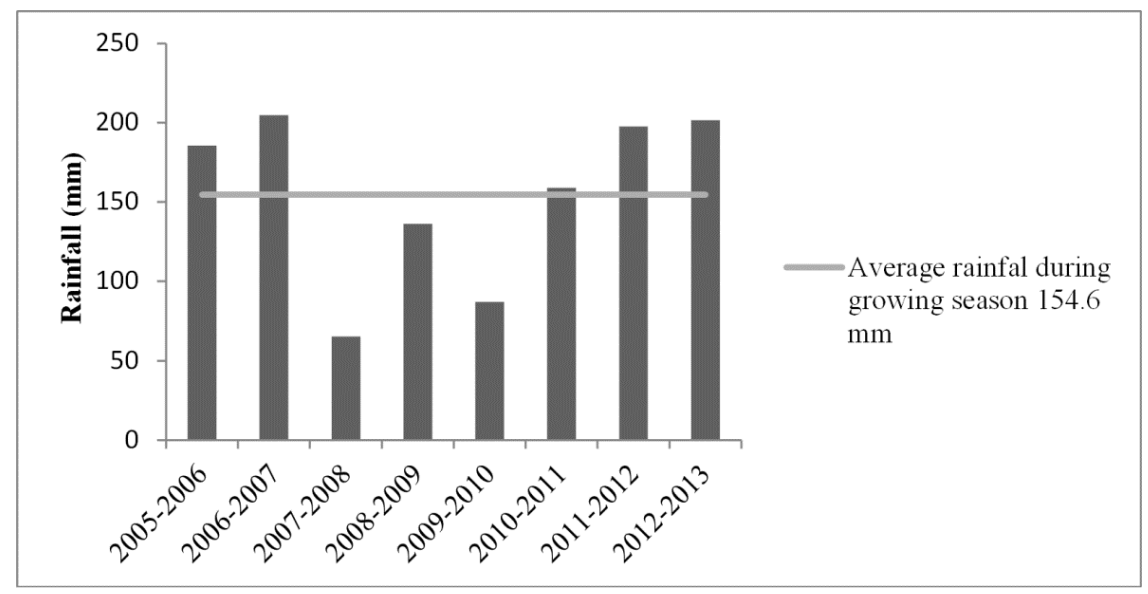

Figure 3. Total rainfall during each growing season and overall average rainfall in Al-Bawi. 


\subsection{Soil Characteristics}

Soil characteristics measured through soil sampling are presented in Table 2 and provide a baseline of textures, which were largely sandy clay loam or loam with high proportions of clay and sand and low levels of organic matter and nitrogen (see Table 2). Similarly, low levels of organic matter, nitrogen and plant-available phosphorous within soils in other areas of Syria have been documented [8].

Table 2. Soil characteristics on the basis of baseline soil sampling for conservation agriculture (CA; P.11 and P.13) and tillage agriculture (TA; P.12 and P.14) in 2011.

\begin{tabular}{ccccccc}
\hline pH (1:1) & $\begin{array}{c}\text { Olsen P } \\
(\mathbf{p p m}){ }^{*}\end{array}$ & $\begin{array}{c}\mathbf{N} \text { Total } \\
(\mathbf{p p m})\end{array}$ & $\begin{array}{c}\text { K Extractable } \\
(\mathbf{p p m})^{*}\end{array}$ & $\mathbf{C a C O}_{3}(\%)$ & OM ** (\%) \\
\hline CA & $8(0.06)$ & $4.7(1.8)$ & $1298.8(158)$ & $299(63)$ & $33.9(1)$ & $2.0(0.3)$ \\
TA & $8(0.20)$ & $4.4(1.0)$ & $1342.4(72)$ & $267(54)$ & $35.6(2)$ & $2.0(0.1)$ \\
\hline & Clay (\%) & Silt (\%) & Sand (\%) & $\begin{array}{c}\text { Bulk Density } \\
\left(\mathbf{g ~ c m}^{-3}\right)\end{array}$ & $\begin{array}{c}\text { Soil Water } \\
\text { Content \% (W/W) }\end{array}$ & C/N Ratio \\
\hline CA & $29(2)$ & $39(4)$ & $31(3)$ & $1.3(0.10)$ & $24.7(1.1)$ & $15.0(0.8)$ \\
TA & $25(3)$ & $38(3)$ & $36(3)$ & $1.3(0.14)$ & $24.0(1.8)$ & $15.1(0.6)$ \\
\hline
\end{tabular}

Notes: On basis of mean of five cores taken; standard deviation in parenthesis; ${ }^{*}$ ppm: measured in parts per million; ** organic matter.

\subsection{Soil Moisture and Hydraulic Conductivity}

Figure 4 shows that the soil moisture contents for CA (P.12) compared to TA (P.13) at peak rainfall periods during the growing season for 2011/2012 were higher under the CA plot $(p<0.05)$. Figure 5 also highlights that the soil under CA had higher moisture rates at different water potential levels. Water potential represents the energy status of water. At saturation, it is $0 \mathrm{kPa}$, and at wilting point, the soil matric potential is $-1500 \mathrm{kPa}(10 \mathrm{~cm}$ is equal to $0.98 \mathrm{kPa}$. We have taken this as roughly a conversion of 10:1; thus $\mathrm{kPa}$ values multiplied by 10 give the values in $\mathrm{cm}(-\mathrm{cm})$. We know that at wilting point, the soil water potential was $-1500 \mathrm{kPa}$ (or $-1.5 \mathrm{MPa}$ ), and the soil moisture content was about $0.15 \mathrm{~cm} \mathrm{~cm}^{-1}$. After $-1500 \mathrm{~cm}$, there was not much change, and the moisture content was around $0.15 \mathrm{~cm} \mathrm{~cm}^{-1}$ (Figure 5). Thus we have excluded this from the graphs, that is, when values were lower than $-1500 \mathrm{~cm}$ ). Moreover, the soil moisture content was significantly higher under CA relative to TA $(p<0.05)$ at different water potential levels observed (see Table 3$)$. The higher soil moisture under CA, measurable immediately in the first 2 years during the period of transition, provides an indication of improved water infiltration and moisture retention capacity under $\mathrm{CA}$ conditions, albeit under transition, relative to TA conditions, with an implication for reductions in water runoff and soil erosion $[3,4,8]$. Given the relative assessment between CA and TA treatments at the same point in time in the growing season, the impact of the higher-than-average rainfall of $197.5 \mathrm{~mm}$ on productivity observed during the 2011/2012 season (see Tables 4 and 5) may improve further with time because of the possible further improvements in rainfall infiltration, water retention, and consequently crop growth, which may occur with further improvement in the soil quality over time. During the 2010/2011 growing season, the rainfall of $159 \mathrm{~mm}$ was close to the average, yet a yield and biomass advantage was recorded in the CA treatment (Figures 3-5). Thus, we would expect the positive differences between CA and TA in rainfall infiltration and water retention to develop into a buffer against drought over time, even during the years when rainfall during the growing season is below average. 


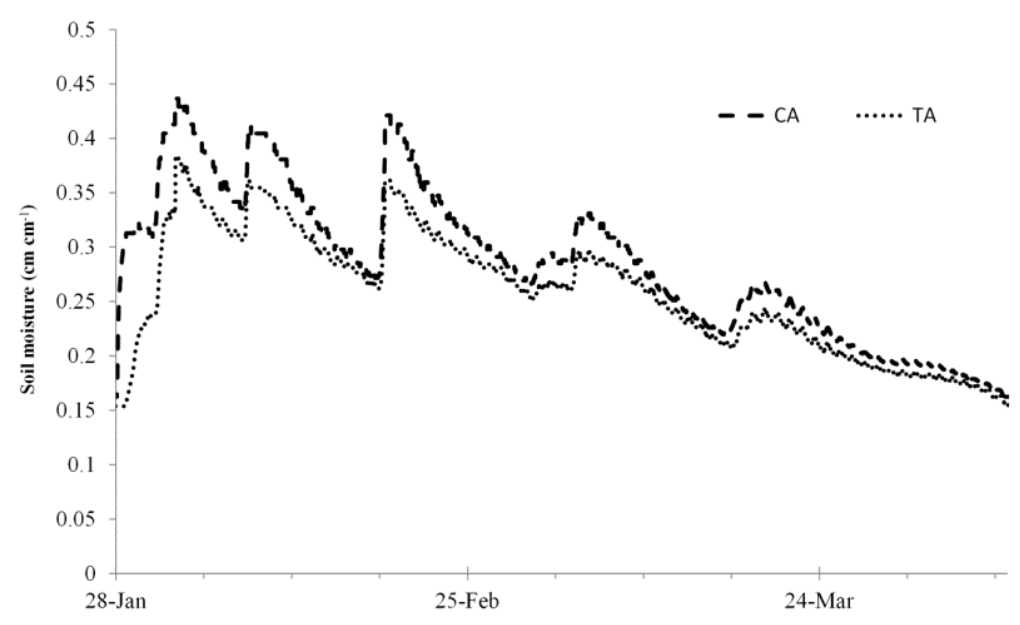

Figure 4. Soil moisture levels for conservation agriculture (CA; P.12) and tillage agriculture (TA; P.13) at peak rainfall periods during the growing season for $2011 / 2012$.

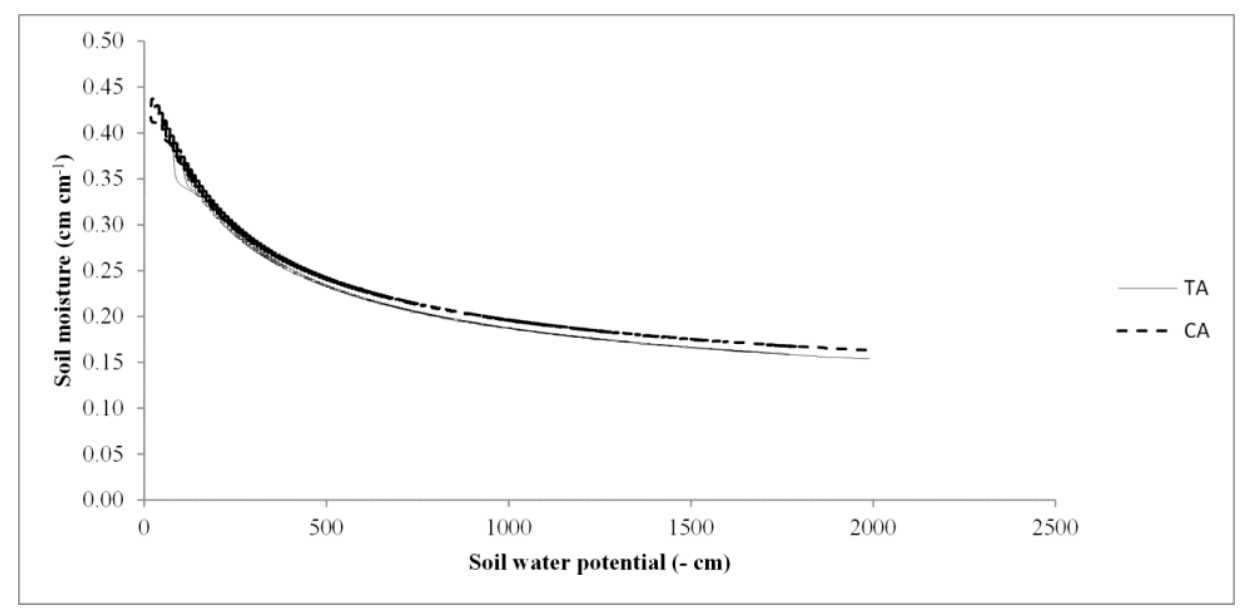

Figure 5. Soil moisture content $\left(\mathrm{cm} \mathrm{cm}^{-1}\right)$ at different water potential levels for conservation agriculture (CA; P.12) and tillage agriculture (TA; P.13).

Table 3. Mean values for soil moisture conservation agriculture (CA; P.13) and tillage agriculture (TA; P.12) at different water potential levels observed $(n=6713)$.

\begin{tabular}{cccc}
\hline $\begin{array}{c}\text { Soil Moisture }\left(\mathrm{cm} \mathrm{cm}^{-\mathbf{1}}\right) \\
\text { (CA) }\end{array}$ & $\begin{array}{c}\mathbf{9 5 \%} \text { Confidence Interval } \\
\text { (CA) }\end{array}$ & $\begin{array}{c}\text { Soil Moisture }\left(\mathrm{cm} \mathrm{cm}^{-\mathbf{1}} \text { ) }\right. \\
\text { (TA) }\end{array}$ & $\begin{array}{c}\mathbf{9 5 \%} \text { Confidence Interval } \\
\text { (TA) }\end{array}$ \\
\hline $0.28(0.69) \mathrm{a}$ & $0.28-0.29$ & $0.26(0.56) \mathrm{b}$ & $0.25-0.26$ \\
\hline
\end{tabular}

Note: Means with different letters denote statistically significant difference at the $5 \%$ level (standard deviation in parenthesis).

Likewise, hydraulic conductivity in the topsoil $(0-20 \mathrm{~cm})$ was also significantly higher under CA $(p<0.05)$ (Figure 6 and Table 4). Hydraulic conductivity or permeability is the capacity of the soil to allow water to pass through its pores or voids. This is likely an indication of increased pore volume and thus soil water retention capacity [29], a result which was also found by [8] in relative comparisons between a no-till system and conventional tillage system. 
Table 4. Mean values for soil hydraulic conductivity conservation agriculture (CA; P.13) and tillage agriculture (TA; P.12) $(n=6713)$.

\begin{tabular}{cccc}
\hline $\begin{array}{c}\text { Soil Hydraulic Conductivity } \\
\text { (cm day }^{-1} \text { ) (CA) }\end{array}$ & $\begin{array}{c}\text { 95\% Confidence } \\
\text { Interval (CA) }\end{array}$ & $\begin{array}{c}\text { Soil Hydraulic Conductivity } \\
\text { (cm day }^{-1} \text { ) (TA) }\end{array}$ & $\begin{array}{c}\text { 95\% Confidence } \\
\text { Interval (TA) }\end{array}$ \\
\hline $0.32(0.65)$ a & $0.31-0.34$ & $0.13(0.21) \mathrm{b}$ & $0.13-0.15$ \\
\hline
\end{tabular}

Note: Means with different letters denote statistically significant difference at the $5 \%$ level (standard deviation in parenthesis).

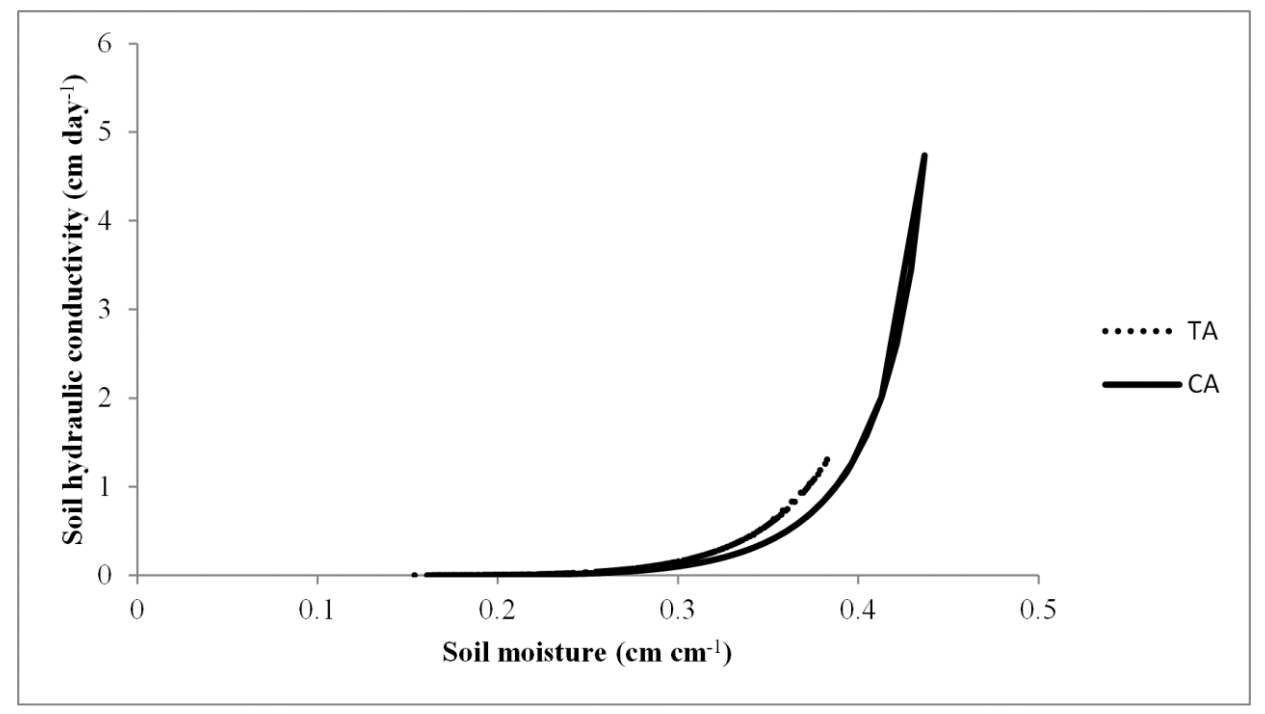

Figure 6. Hydraulic conductivity $\left(\mathrm{cm} \mathrm{day}^{-1}\right)$ in the topsoil $(0-20 \mathrm{~cm})$ for conservation agriculture (CA; P.12) and tillage agriculture (TA; P.13).

\subsection{Yield, Economic Returns and Market Linkages}

The results indicate that even during the first 2 years of transition into $C A$, there existed gains for CA yields in the second year for barley intercropped with atriplex and salsola (Table 5) and promising signs of improvement in the grain and straw biomass produced (Tables 5 and 6). Interestingly, if the opportunity cost of mulch is not accounted for, CA would have been more profitable in the first year onwards for the alternative crop mix (Table 6).

Table 5. Yields $\left(\mathrm{kg} \mathrm{ha}^{-1}\right)$ and partial budget (USD/ha) for conservation agriculture (CA; P.12) and tillage agriculture (TA; P.13) for 2010/2011 and 2011/2012 seasons.

\begin{tabular}{ccccc}
\hline & \multicolumn{2}{c}{ CA } & \multicolumn{2}{c}{ TA } \\
\hline Budget Item & $\mathbf{2 0 1 0 / 2 0 1 1} *$ & $\mathbf{2 0 1 1 / 2 0 1 2} * *$ & $\mathbf{2 0 1 0 / 2 0 1 1} *$ & $\mathbf{2 0 1 1 / 2 0 1 2} * *$ \\
\hline Grain yield (barley/ervilia) & 250.0 & 980.0 & 280.0 & 1040.0 \\
Straw yield & 380.0 & 2300.0 & 690.0 & 2040.0 \\
Grain value & 135.0 & 392.0 & 151.2 & 416.0 \\
Straw value & 53.2 & 414.0 & 96.6 & 367.2 \\
Opportunity cost of mulch & 53.2 & 414.0 & & 40.0 \\
Seed cost & 54.0 & 40.0 & 54.0 & 10.0 \\
Seeding cost & 12.0 & 15.0 & 10.0 & 33.0 \\
Fertilizer cost & 18.0 & 33.0 & 18.0 & 14.0 \\
Land preparation, i.e., ploughing & & & 8.0 & 97.0 \\
Total production costs & 137.2 & 502.0 & 90.0 & 783.2 \\
Total revenue & 188.2 & 806.0 & 247.8 & 686.2 \\
Net revenue & 51.0 & 304.0 & 157.8 & \\
\hline
\end{tabular}

Note: ${ }^{*}$ Ervilia intercropped with atriplex and salsola; ${ }^{* *}$ barley intercropped with atriplex and salsola. 
Table 6. Yields ( $\mathrm{kg} \mathrm{ha}^{-1}$ ) and partial budget (USD/ha) analysis of conservation agriculture (CA; P.11) and tillage agriculture (TA; P.14) for 2010/2011 and 2011/2012 seasons.

\begin{tabular}{ccccc}
\hline & \multicolumn{2}{c}{ CA } & \multicolumn{2}{c}{ TA } \\
\hline Budget Item & $\mathbf{2 0 1 0 / 2 0 1 1} *$ & $\mathbf{2 0 1 1 / 2 0 1 2} * *$ & $\mathbf{2 0 1 0 / 2 0 1 1}$ & $\mathbf{2 0 1 1 / 2 0 1 2}$ ** \\
\hline Grain yield (barley/ervilia) & 170.0 & 870.0 & 130.0 & 590.0 \\
Straw yield & 910.0 & 2760.0 & 460.0 & 1300.0 \\
Grain value & 54.4 & 469.8 & 41.6 & 318.6 \\
Straw value & 54.6 & 651.4 & 27.6 & 306.8 \\
Opportunity cost of mulch & 54.6 & 651.4 & & 56.4 \\
Seed cost & 32.0 & 56.4 & 32.0 & 10.0 \\
Seeding cost & 12.0 & 15.0 & 10.0 & 21.0 \\
Fertilizer cost & 18.0 & 21.0 & 18.0 & 14.0 \\
Land preparation, i.e., ploughing & & & 8.0 & 87.4 \\
Total production costs & 116.6 & 743.8 & 60.0 & 625.4 \\
Total revenue & 109.0 & 1121.2 & 69.2 & 538.0 \\
Net revenue & -7.6 & 377.4 & 9.2 & \\
\hline
\end{tabular}

Note: * Seeded with barley intercrop with atriplex and salsola; ${ }^{* *}$ seeded with a mixture of barley $(30 \%)$ and ervilia $(70 \%)$ and intercropped with atriplex and salsola.

In fact, straw yields under CA for plot P.14 (Table 6) in 2011/2012 were more than double those of TA (i.e., conventional tillage). Similar yield gains have also been reported [5] for CA under a barley and vetch mixture in Lebanon, a region with a much higher average annual rainfall $(550 \mathrm{~mm})$. For semi-arid and dry Mediterranean environments, we estimate, on the basis of information from various sources for barley and wheat [30-35], that at least some $0.5 \mathrm{t} \mathrm{ha}^{-1}$ of crop biomass residue is needed in order to provide a $30 \%$ ground cover.

In the 2011/2012 season, under a barley and ervilia seeded mixture (Table 6), the straw biomass production was greater than the $0.5 \mathrm{t} \mathrm{ha}^{-1}$ required to cover $30 \%$ of the soil surface, that is, roughly $2.7 \mathrm{tha}^{-1}$ (i.e., $2700 \mathrm{~kg} \mathrm{ha}^{-1}$ ). We found that the optimum amount that could be put down was $2000 \mathrm{~kg} \mathrm{ha}^{-1}$, that is, approximately $2 \mathrm{t} \mathrm{ha}^{-1}$ (i.e., roughly 4 times as much as is required for some $30 \%$ ground cover). Moreover, during the first year under study, for the same crop mix, we calculated the optimum amount that could be put down as ground cover to be $0.63 \mathrm{t} \mathrm{ha}^{-1}$ (i.e., $630 \mathrm{~kg} \mathrm{ha}^{-1}$ ). This was because any greater amount put down as mulch under the CA system would make a financial loss relative to the conventional system, given the opportunity cost of mulch. Likewise, for the crop mix presented in Table 5, it was only feasible to put down roughly $170 \mathrm{~kg} \mathrm{ha}^{-1}$ in the second year (i.e., 2011/2012) — any greater amount would have resulted in a financial loss relative to the conventional system.

This highlights the importance of crop mix to the profitability of CA relative to the conventional system. Another argument is that straw biomass, applied as ground cover, should be considered as an economic investment for future benefits in the form of better soil health, increased productivity and resilience, and higher and more reliable profit. However, farmers, and particularly poor and marginal farmers, are likely to be more myopic and cost conscious as opposed to investment savvy.

How to bridge this short-term deficiency becomes a key question for innovation systems to address. Our analysis, however, excludes other costs such as labor, which may provide additional gains for the CA system relative to the TA system (see [5]). The results support the contention that even in very dry areas, enough biomass can be generated (and increased over time) to allow for in situ mulching of crop residues produced from the cropping system to meet the minimum CA requirement for ground cover, that is, $30 \%$ surface coverage. It has been suggested by [21] that the trade-off for feeds and livestock may not be as pronounced given the increase in biomass that offsets the input of the mulch residue retained. We agree with the assessment of [21] but note that the time-lag in reaching a sufficient level of increase in biomass may be a deterrent to wide-scale adoption, even where there is already a utilization of straw for ground cover as well as the simultaneous feeding of livestock. 
This is because it is possible to start harnessing economic and environmental benefits during the early transitional years of the CA adoption process while still building up biomass output, soil mulch cover and soil health.

Further, the in situ production of biomass from the cropping system (which would be enough to maintain a $30 \%$ ground cover) may certainly be possible in an above-average or good rainfall year, particularly in the initial stages of CA establishment. However, progress can be made where the commitment for residue retention is managed through improved grazing, such as rotational grazing agreed upon by all sides, including at the community level.

There are clear trade-offs that exist in marginal dryland areas at the start of the transformational process to establish a CA system, particularly within a setting in which livestock is central to crop farmers' and pastoralists' livelihoods, and where fodder biomass (straw) production is valued more highly over grain production. Moreover, this is exacerbated in a region with frequent droughts and dry spells. It has been estimated [36] that the shadow value of straw in a drought year is 3-fold the price of grain, signifying its importance to crop-livestock farming communities for which crop-livestock integration is based on pastoralists relying on access to fodder produced by settled farmers. The value of fodder during the growing season and of straw during the dry season, particularly in a drought year, may however further complicate the problem noted by [8], where difficulties were found in farmers adopting CA in Syria as a result of competing uses of biomass for livestock. Thus, [5] notes the importance of conducting research to determine the "optimum quantity of crop residues" that can be retained for ground cover without restricting the amount of biomass needed for livestock, whilst also ensuring that enough residues are left on the soil surface to capture the full productivity, socio-economic and environmental benefits that can occur over time.

Notwithstanding this, there are a number of options that exist within many dry environments, which may enhance the variety of feed sources available and thereby limit or minimize the competition between crop biomass (including post-harvest waste) for livestock feeding and that required for building and maintaining ground cover under CA. In Syria, the prominence of olive trees and pruning waste provides one avenue-as do other forms of compostable waste. Grass, leaf litter and other dead-plant biomass may also be utilized as a source of ground cover, and these are showing promise in parts of sub-Saharan Africa [37]. Suggestions have also been made to incorporate a range of agro-industrial waste combinations into supplemental sources of livestock feed (e.g., molasses and olive-oil pomace) with potential beneficial outcomes for joint products produced-such as milk and yoghurt quantity and quality [38]. Supplementary feed sources may thus reduce the amount of feed needed from crop fodder biomass and residues.

From the standpoint of a collaborative research and developmental initiative, there are also likely to be significant gains made in assessing the efficacy of testing contractual agreements between farmers in marginal zones and farmers within irrigated zones. Given that barley is no longer protected under government subsidy support, at least at the time of this study or likely in a stable Syria in the future, there is a need to appeal to the incentives for barley production between zones. As previously mentioned, the incentive in irrigated areas is for grain production, with straw biomass a joint by-product typically sold into the market for supplementary livestock feeding. The potential for farmers in marginal zones to contract farmers in irrigated areas for the production of both grain suitable for their production environments (drought tolerant or locally adapted) and straw has yet to be tested and validated. It would appear that the incentives for both cohorts of farmers would be aligned under such an arrangement, and particularly so given that rainfall levels within marginal zones do not permit the regular production of grain or therefore a continued reliance on nascent (local) grain markets. Why such contractual arrangements have not taken root organically is an equally important research question. One conjecture is that the markets for rural finance (credit, insurance, and deposits) in Syria are still not mature enough to handle such arrangements; they therefore risk mitigating the potential for efficiency in contractual agreements across agro-ecological zones. 


\subsection{Land Rental Markets, Rural Finance and Social Stability}

As has been mentioned repeatedly, the key incentive for the production of barley within marginal zones in Syria is as green and dry fodder for livestock. Grain is only produced in years of adequate and timely rainfall. There is, however, a qualifier to this statement. The production of fodder and dry straw, as the primary economic objective, is not in the form of a harvested product but rather an in situ product for on-site consumption by nomadic livestock. It is the ability to capitalize on land rental rates for direct grazing that is the key motivation for producing a stand of fodder barley and often a stand without any grain production. Why does this observance interest us in a study on the relevance and broad applicability for CA in marginal zones?

Firstly, in an environment where access to credit has typically been constrained, the provision of microfinance within rural communities has played a significant role in relaxing working capital constraints such that greater areas of marginal land are brought into production. Reliable statistics in Syria are difficult to acquire, and in many cases, they have been pencil-marked in order to ensure that they are consistent with regulatory rules and ordinances. It is difficult therefore to support this claim of a correlation between microfinance availability and the increased amount of marginal land under production. Easier to justify is the argument that standardized norms for the disbursement of microfinance across zones, on the basis of a set monetary value per unit of land, will inherently benefit farmers in marginal zones. Given that quantities and costs of material inputs such as fertilizer and specifically irrigation are much higher for farmers in irrigated areas, fixed rates per unit of land provide marginal farmers with both working capital and an excess of funds to be used in order to smooth out consumption over the growing season.

The incentives to bring more land under production with simplified rules for microfinance are therefore clear. With land rental values for direct grazing increasing within periods of drought, the ability to pay back loans is bolstered. When more productive land use paradigms such as CA offer the potential for improved reliability in yields as well as savings in costs, the incentives for bringing more land into production are greater, and as is the ability to repay loans at the end of the growing season. Microfinance, when coupled with improvements in land use management practices such as CA, has the potential to improve both adoption rates (measured in terms of land under CA) as well as rural household livelihoods through an ability to smooth out consumption throughout the year-notwithstanding improvements in profitability from cropping in marginal zones. The inherent outcomes attainable from the broad adoption of CA are therefore not restricted solely to savings in production costs and beneficial productivity and environmental outcomes (soil health among others), but also are in terms of improving the quality of life for rural households through improving the security of income streams and a reduction in vulnerability from systemic shocks.

Secondly, the ability to capitalize on land rental rates for direct grazing is of immense importance in periods of drought, given the nature of pastoral livelihood systems within the region, and in Syria more specifically. Within an era of subsidized barley production and distribution, it was not uncommon for Bedouins to settle within the vast and often barren rangelands and to rely on a network of marketing agents who supplied subsidized barley, water and necessities of life to their communities. With the removal of state subsidy programs, there has been increased movement of livestock flocks and, in periods of drought, frequent clashes and disputes between settled farmers and nomadic flock herders. Options under CA land use, such as "managed" rotational grazing and/or "communal agreements" at the village/community level for balancing stocking rates with livestock carrying capacity, are applicable as measures for mitigating conflicts [3]. However, these are very much dependent on land use rights and security in land use rights. While there have been significant challenges in the development of a land cadastral system and the issuance of certificates of land ownership, land rental markets have strengthened and continue to strengthen with increased availability of credit (at least prior to the civil conflict in 2011). Improved productivity and the reliability of the production on marginal lands, through shifts in land use management paradigms, are therefore likely to bode well for reducing conflicts between settled farmers and pastoral herders. There is an element of fostering social 
stability and the reduction of conflict within the set of outcomes desired from the broad adoption of $\mathrm{CA}$, and this is sometimes missed given that much research and attention related to the broad adoption of CA has been within more stable environments.

\subsection{Enhancing Broad Adoption of CA through Lessons Learned}

One of the major limitations of this study was the inability to follow up on the baseline soil sampling, given difficulties in access to the field in light of armed conflict and the heightened lack of security. Similarly, caution should also be used in generalizing the yield and economic returns, given the lack of replicability in the trial demonstration site. Given that the initial objective of the field sites was for on-farm demonstration, these results provide an indication of the validity of the proof of concept and of the applicability for CA to potentially succeed in the marginal dryland environments under which it was tested. Thus, we were unable to ascertain the full impact of the various treatments on soil biological, chemical, hydrological and physical properties and on the cropping system and land productivity and resilience over time, but were buoyed by initial results, which were encouraging. Although the need to replicate the trials should also be considered in future research, a number of published on-farm managed trials have been unreplicated yet have yielded useful insights (see, e.g., [39]). Moreover, other authors have noted that a trial design with no replication on a farmer's field simplifies the demonstration, thereby making it easier for farmers to understand and evaluate the technology [40].

What is worth noting is that wherever CA has been practiced in dryland Mediterranean environments for more than 10 or 15 years, such as in Western Australia, South Africa and southern Europe, the benefits include improved biomass and yield outputs, as soil organic matter and soil health improved with time but also reduced the use of the purchased inputs of seeds, nutrients, pesticides, fuel, water and time, in addition to a reduction in soil erosion and land degradation [41-44]. Such benefits have often led to an increase in the livestock carrying capacity and stocking rates. In Western Australia, with its dryland Mediterranean environment, CA farmers are able to cultivate sustainably and profitably with $200 \mathrm{~mm}$ of rainfall [41,43]. It would therefore seem probable that such benefits would be potentially available to farmers in Syria, making it attractive to establish CA crop-livestock systems in which crops and livestock can co-exist productively and sustainably through various forms of win-win integration involving viable arrangements at all levels of rural organizations.

Within the West Asia and North Africa region, agricultural advisory services have largely been within the domain of national systems of agricultural extension. In Syria, the inclusion of non-governmental and international organizations (both research and development) was very recent, with expansion taking place after the death of the last President Hafez Al Assad in 2000, and with initial support from his now President son Bashar Al Assad. A discussion on the background for why more pluralistic forms of knowledge dissemination were not permitted in Syria is a topic for another paper. The general point, and a more global point at that, is that perspectives on the role of agricultural innovation have shifted considerably, moving from linear transfer-of-technology models in the 1960s to, more recently, a focus on agricultural innovation systems (AISs). AISs argue that both the development and adoption of contextually relevant technologies and innovations are more likely to be successful when there is a process of continuous learning, jointly undertaken by research organizations, farmers, marketing agents, donors, Non-governmental organizations (NGOs), financial service providers, policy makers, and relevant civil society actors.

Notwithstanding that Syria is currently embroiled in a civil war, there is an unanswered question of whether nations within the region are ready to embrace participatory learning in order to uncover inclusive systems development approaches for (i) identifying and sharing contextually relevant sets of interlinked practices for research and development, (ii) uncovering avenues for strengthening capacities in effectively adapting and adopting paradigm changing agricultural technologies and best practices, and (iii) providing rural communities with an opportunity for greater participation in regional and national policy dialogue. 
The success in the adoption of CA globally has been attained in favorable and unfavorable environments, including in dryland Mediterranean environments, such as in Europe, central Asia, South Africa and Australia [3-5,7,10]. Thus, we speak to the question of enabling investment and regulatory policies as well as social and cultural environments that support knowledge, participatory learning and the enhancing of the national capacity to innovate.

While there is anecdotal evidence to suggest that no-till agriculture has been broadly accepted in Syria, one could easily argue that this has been fostered by shortages in fuel, within the post-revolution period, which has influenced a move towards limiting machinery use for tillage in crop establishment and in weed management. In the period prior to the revolution (2008-2011), there were claims that over 30,000 ha in Syria was under no-till systems [21,45-48]. How much of this was influenced through incentives provided by donor funds (gratis use of machinery and equipment, complimentary seed distribution, etc.) and disseminated through research and public extension organizations is not clear and is not well documented. Whether this trend will reverse itself in a stable Syria remains, therefore, to be assessed and is a valid question for future research. What is clear is that without supporting systems for participatory knowledge generation and dissemination, together with an enabling investment and policy environment, the ability for the broad adoption of CA and the desired environmental, social and economic outcomes are likely to be limited.

\section{Concluding Remarks}

CA was shown to maintain higher levels of soil moisture $(p<0.05)$ over the growing season, together with improved hydraulic conductivity, when demonstrated within a dry and marginal agro-ecological zone in central Syria. Notwithstanding the limitations of short-term results such as these, and although it is difficult to ascertain whether there are statistically significant differences in yields within this study (or visible trends in the medium to long term), there were clear economic advantages in the adoption of CA produced in the first two seasons of adoption and system transformation. These included a reduction in fuel used for crop establishment and weeding, which has a particular relevance for the region given the recent fuel and input shortages, within an era of ongoing armed civil conflict. There is also preliminary evidence to support the contention that CA can improve yield and biomass output and overall net returns (although crop mix is important), even in the driest agro-ecological zones. The preliminary results also suggest (at least in the short term) that residue retention may not immediately fulfil the requirements of 30\% ground cover for CA and that this may be more difficult to maintain in a drought year. This is due to the marginal nature of the environment and the strong crop-livestock interaction. However, there is evidence that it should be possible to establish and maintain minimum ground cover as greater crop and land potentials are mobilized during the early transitional phase of CA adoption.

The role of soil mulch cover is to improve soil health and biology as well as to provide physical surface protection against soil erosion, suppress weeds and sustain food webs below and above the ground. Thus, soil mulch cover will always remain an important component of CA, however difficult it may be to maintain it against the pressures from and the competition with livestock. The increase in yields vis-à-vis improvements in biophysical parameters in CA relative to TA does suggest, however, that the competition with livestock for biomass is likely to reduce over time and that farmers would be able to return increased levels of straw (as stubble and residue) as mulch, given improved biomass yields. Our data supports previous research in the region on CA, or components of CA cited herein, and also provides an indication that $\mathrm{CA}$ has a beneficial role to play in marginal cropping zones such as that under study.

These benefits are much broader than those ascribed to beneficial environmental outcomes and increased profitability through a reduction in production costs and higher yields. We argue that in marginal zones with interactions between pastoralists and settled farmers, and thereby with strong crop-livestock interactions, the CA approach to sustainable intensification has the potential to also foster beneficial outcomes in terms of improvements in social stability, in potentially smoothing out 
seasonal consumption needs (household and livestock) when supported through inclusive finance provision, and in reducing risks from systemic shocks. The key to the broad adoption of CA in marginal environments is a supportive and enabling environment for participatory innovation, comprised of both research (invention) and avenues for the dissemination of knowledge, which influences shifts in land use management practices (adoption) at all levels, including the community level, within production systems and across components of crop production and livestock production. How ready Syria is for fostering inclusive and enabling environments for agricultural innovation, and towards the attainment of critical mass in the adoption of sustainable long-term shifts towards environmentally, socially and economically sound land use management practices, is a question for future research to answer within a stable environment. The applied research initiative reported herein suggests that there are significant reasons for hope and promise.

Acknowledgments: This work was supported by The Norwegian Ministry of Foreign Affairs under a (non-numbered) grant to the Aga Khan Foundation (UK) and was implemented by the Aga Khan Foundation (Syria). The views and opinions expressed in this manuscript may not necessarily reflect those of the Aga Khan Foundation, its affiliated agencies within the Aga Khan Development Network, or the Foundation's collaborative partners. The authors express their appreciation to Dr. Rolf Sommer (CIAT) for support with the use of Rosetta software and soil sampling and Dr. Muhi El-Dine Hilali (ICARDA) for helpful discussions, which supported the development of this manuscript. The authors would also like to thank all of the staff at the Aga Khan Foundation (Syria) for valuable support in field-based/project implementation activities. We are particularly grateful to Yaser Mousa, Mohanad Obaido, Feras Jakish, Rasha Faraj, Nasr Eid, Karim Al-Hamwi, Osama Sameh, Hasan Alsaleeb, Ismaili Khateeb and Humam Al-Herk.

Author Contributions: Baqir Lalani, Bassil Aleter, Shinan N. Kassam, Amyn Bapoo and Amir Kassam jointly designed the study. Baqir Lalani and Bassil Aleter analysed the data. Baqir Lalani, Bassil Aleter, Shinan N. Kassam, Amyn Bapoo and Amir Kassam jointly wrote the manuscript. All authors approved the final version of the manuscript.

Conflicts of Interest: The authors declare no conflict of interest.

\section{References}

1. FAO CA Adoption Worldwide. Available online: http://www.fao.org/ag/ca/6c.html (accessed on 16 January 2016).

2. Mrabet, R.; Moussadek, R.; Fadlaoui, A.; van Ranst, E. Conservation agriculture in dry areas of Morocco. Field Crop. Res. 2012, 132, 84-94. [CrossRef]

3. Kassam, A.; Friedrich, T.; Derpsch, R.; Lahmar, R.; Mrabet, R.; Basch, G.; González-Sánchez, E.J.; Serraj, R. Conservation agriculture in the dry Mediterranean climate. Field Crop. Res. 2012, 132, 7-17. [CrossRef]

4. Kassam, A.; Basch, G.; Friedrich, T.; Shaxson, F.; Goddard, T.; Amado, T.; Crabtree, B.; Hongwen, L.; Mello, I.; Pisante, M.; et al. Sustainable soil management is more than what and how crops are grown. In Principles of Sustainable Soil Management in Agroecosystems; CRC Press: Boca Raton, FL, USA, 2013.

5. Bashour, I.; AL-Ouda, A.; Kassam, A.; Bachour, R.; Jouni, K.; Hansmann, B.; Estephan, C. An overview of Conservation Agriculture in the dry Mediterranean environments with a special focus on Syria and Lebanon. AIMS Agric. Food 2016, 1, 67-84. [CrossRef]

6. Gonsalez-Sanchez, E.J.; Veroz-Gonsalez, O.; Blanco-Roldan, G.L.; Marquez-Garcia, F.; Carbonell-Bojollo, R. A renewed view of conservation agriculture and its evolution over the last decade in Spain. Soil Tillage Res. 2014, 146, 204-212. [CrossRef]

7. Kassam, A.; Friedrich, T.; Derpsch, R.; Kienzle, J. Overview of the worldwide spread of Conservation Agriculture. Field Actions Sci. Rep. 2015, 8, 1-10.

8. Sommer, R.; Piggin, C.; Feindel, D.; Ansar, M.; Delden, L.V.; Shimonaka, K.; Abdalla, J.; Douba, O.; Estefan, G.; Haddad, A.; et al. Effects of zero tillage and residue retention on soil quality in the mediterranean region of Northern Syria. Open J. Soil Sci. 2014, 4, 109-125. [CrossRef]

9. Jat, R.; Sahrawat, K.; Kassam, A. Conservation Agriculture: Global Prospects and Challenges; CABI: Wallingford, UK, 2014.

10. Nurbekov, A.; Akramkhanov, A.; Kassam, A.; Sydyk, D.; Ziyadaullaev, Z.; Lamers, J.P.A. Conservation Agriculture in combating land degradation in Central Asia: A sysnthesis. AIMS Agric. Food 2016, 1, 144-156. [CrossRef] 
11. Rasmussen, P.E.; Collins, H.P.; Smiley, R.W. Long-Term Management Effects on Soil Productivity and Crop Yield in Semi-Arid Regions of Eastern Oregon; Agricultural Experiment Station: Corvallis, OR, USA, 1989.

12. Masri, Z.; Ryan, J. Soil organic matter and related physical properties in a Mediterranean wheat-based rotation trial. Soil Tillage Res. 2006, 87, 146-154. [CrossRef]

13. Wahbi, A.; Miwak, H.; Singh, R. Effects of Conservation Agriculture on Soil Physical Properties and Yield of Lentil in Northern Syria. In Geophysical Research Abstracts; EGU General Assembly Conference Abstracts; Copernicus Publications: Munich, Germany, 2014; Volume 16, p. 3280.

14. Powlson, D.S.; Stirling, C.M.; Jat, M.L.; Gerard, B.G.; Palm, C.A.; Sanchez, P.A.; Cassman, K.G. Limited potential of no-till agriculture for climate change mitigation. Nat. Clim. Chang. 2014, 4, 678-683. [CrossRef]

15. Pittelkow, C.M.; Liang, X.; Linquist, B.A.; Van Groenigen, K.J.; Lee, J.; Lundy, M.E.; van Gestel, N.; Six, J.; Venterea, R.T.; van Kessel, C. Productivity limits and potentials of the principles of conservation agriculture. Nature 2015, 517, 365-368. [CrossRef] [PubMed]

16. Jat, M.L.; Dagar, J.C.; Sapkota, T.B.; Yadvinder-Singh; Govaerts, B.; Ridaura, S.L.; Saharawat, Y.S.; Sharma, R.K.; Tetarwal, J.P.; Jat, R.K.; et al. Climate Change and Agriculture: Adaptation Strategies and Mitigation Opportunities for Food Security in South Asia and Latin America. Adv. Agron. 2016, 137, 127-235.

17. Li, H.; He, J.; Bharucha, Z.P.; Lal, R.; Pretty, J. Improving China's food and environmental security with conservation agriculture. Int. J. Agric. Sustain. 2016, 14, 377-391. [CrossRef]

18. Thierfelder, C.; Chivenge, P.; Mupangwa, W.; Rosenstock, T.S.; Lamanna, C.; Eyre, J.X. How climate-smart is conservation agriculture (CA)? - Its potential to deliver on adaptation, mitigation and productivity on smallholder farms in southern Africa. Food Secur. 2017, 9, 537-560. [CrossRef]

19. Sommer, R.; Ryan, J.; Masri, S.; Singh, M.; Diekmann, J. Effect of shallow tillage, moldboard plowing, straw management and compost addition on soil organic matter and nitrogen in a dryland barley/wheat-vetch rotation. Soil Tillage Res. 2011, 115-116, 39-46. [CrossRef]

20. Pala, M.; Harris, H.C.; Ryan, J.; Makboul, R.; Dozom, S. Tillage Systems and Stubble Management in a Mediterranean-Type Environment in Relation to Crop Yield and Soil Moisture. Exp. Agric. 2000, 36, $223-242$. [CrossRef]

21. Piggin, C.; Haddad, A.; Khalil, Y.; Loss, S.; Pala, M. Effects of tillage and time of sowing on bread wheat, chickpea, barley and lentil grown in rotation in rainfed systems in Syria. Field Crop. Res. 2015, 173, 57-67. [CrossRef]

22. Jones, M.J.; Arous, Z. Barley-Salt-Bush Intercropping for Sustainable Feed Production in a Dry Mediterranean Steppe Environment. J. Agron. Crop Sci. 2000, 184, 253-260. [CrossRef]

23. De Freitas, P.L.; Landers, J.N. The transformation of agriculture in Brazil through development and Adoption of Zero Tillage Conservation Agriculture. Int. Soil Water Conserv. Res. 2014, 2, 35-46. [CrossRef]

24. Kassam, A.; Friedrich, T.; Shaxson, F.; Bartz, H.; Mello, I.; Kienzle, J.; Pretty, J. The spread of conservation agriculture: Policy and institutional support for adoption and uptake. Field Actions Sci. Rep. 2014, 7, 1-12.

25. Rajalahti, R. Sourcebook overview and user guide. In Agricultural Innovation Systems, an Investment Sourcebook; World Bank: Washington, DC, USA, 2012; pp. 1-13.

26. Sanyang, S.; Pyburn, R.; Mur, R.; Audet-Bélanger, G. Against the Grain and to the Roots: Maize and Cassava Innovation Platforms in West and Central Africa; Royal Tropical Institute: Amsterdam, The Netherlands, 2014.

27. Ministry of Agriculture and Agrarian Reform (MAAR). Agricultural Statistics, Ministry of Agriculture and Agrarian Reform; MAAR: Damascus, Syria, 2007.

28. Van Genuchten, M.T. A closed-form equation for predicting the hydraulic conductivity of unsaturated soils. Soil Sci. Soc. Am. J. 1980, 44, 892-898. [CrossRef]

29. Verhulst, N.; Govaerts, B.; Verachtert, E.; Castellanos-Navarrete, A.; Mezzalama, M.; Wall, P.; Deckers, J.; Sayre, K. Conservation agriculture, improving soil quality for sustainable production systems. In Advances in Soil Science: Food Security and Soil Quality; Lal, R., Stewart, B.A., Eds.; CRC Press: Boca Raton, FL, USA, 2010; pp. 137-208.

30. Dicky, E.C.; Havlin, J.H. Estimating Crop Residue: Using Residue to Help Control Wind and Water Erosiuon; Biological Systems Engineering: Madison, WI, USA, 1985.

31. United States Department of Agriculture (USDA). Picture Your Residue; Soil Conservation Service; SCS-CRM-02 April 1992; USDA: Washington, DC, USA, 1992.

32. Lyon, D.J.; Christensen, R.A. Estimating Winter Wheat Residue Cover; Lincoln Extension Paper 4687; University of Nebraska: Lincoln, NE, USA, 1992. 
33. McCarthy, J.R.; Pfost, D.L.; Currenece, H.D. Conservation Tillage and Residue Management to Reduce Soil Erosion. 1993. Available online: http:/ / extension.missouri.edu/p/G1650 (accessed on 26 November 2017).

34. Scott, B.J.; Eberbach, P.L.; Evans, J.; Wde, L.J. Stubble Retention in Cropping Systems in Southern Australia: Benefits and Challenges. EH Graham Centre for Agricultural Innovation. 2010. Available online: https://www.csu.edu.au/research/grahamcentre/publications/monograph/stubble-retentionin-cropping-systems-in-southern-australia-benefits-and-challenges (accessed on 26 November 2017).

35. British Columbia, Ministry of Agriculture. Estimating Crop Residue Cover for Soil Erosion Control; Soil Factsheet; Order No. 641 220-1; British Columbia, Ministry of Agriculture: Victoria, BC, Canada, 2015.

36. Magnan, N.; Larson, D.M.; Taylor, J.E. Stuck on stubble? The non-market value of agricultural byproducts for diversified farmers in Morocco. Am. J. Agric. Econ. 2012, 94, 1055-1069. [CrossRef]

37. Thierfelder, C.; Rusinamhodzi, L.; Ngwira, A.R.; Mupangwa, W.; Nyagumbo, I.; Kassie, G.T.; Cairns, J.E. Conservation agriculture in Southern Africa: Advances in knowledge. Renew. Agric. Food Syst. 2015, 30, 328-348. [CrossRef]

38. Solh, M.; van Ginkel, M. Drought preparedness and drought mitigation in the developing world's drylands. Weather Clim. Extremes 2014, 3, 62-66. [CrossRef]

39. Grace, P.; Oades, J.; Keith, H.; Hancock, T. Trends in wheat yields and soil organic carbon in the Permanent Rotation Trial at the Waite Agricultural Research Institute, South Australia. Aust. J. Exp. Agric. 1995, 35, 857-864. [CrossRef]

40. Snapp, S. Quantifying farmer evaluation of Technologies: Mother and Baby Trial. In Quantitative Analysis of Data from Participatory Methods in Plant Breeding; Bellon, M.R., Reeves, J., Eds.; CIMMYT: Texcoco, Mexico, 2002.

41. Crabtree, B. Search for Sustainability with No-Till Bill in Dryland Agriculture; Crabtree Agriculture Consulting: Beckenham, UK, 2010.

42. Basch, G.; Kassam, A.H.; Friedrich, T.; Santos, F.L.; Gubiani, P.I.; Calegari, A.; Reichert, J.M.; Dos Santos, D.R. Sustainable soil water management systems. In Soil Water and Agronomic Productivity; Lal, R., Stewart, B.A., Eds.; Advances in Soil Science; CRC Press: Boca Raton, FL, USA, 2012; pp. 229-288.

43. Rochecouste, J.; Crabtree, B. Conservation Agriculture in Australian Dryland Cropping. In Conservation Agriculture: Global Prospects and Challenges; Jat, R.A., Sahrawat, K.L., Kassam, A.H., Eds.; CABI: Wallingford, UK, 2014.

44. Friedrich, T.; Kassam, A.H.; Corsi, S. Conservation Agriculture in Europe. In Conservation Agriculture: Global Prospects and Challenges; Jat, R.A., Sahrawat, K.L., Kassam, A.H., Eds.; CABI: Wallingford, UK, 2014; pp. 127-179.

45. Piggin, C.; Haddad, A.; Khalil, Y. Development and Promotion of Zero Tillage in Iraq and Syria. In Proceedings of the 5th World Congress on Conservation Agriculture Incorporating 3rd Farming Systems Design Conference, Brisbane, Australia, 26-29 September 2011; pp. 304-305.

46. Haddad, N.; Piggin, C.; Haddad, A.; Kahlil, Y. Conservation Agriculture in West Asia. In Conservation Agriculture: Global Prospects and Challenges; Jat, R.A., Sahrawat, K.L., Kassam, A.H., Eds.; CABI: Wallingford, UK, 2014; pp. 248-262.

47. Loss, S.; Haddad, A.; Khalil, Y.; Alrijabo, A.; Feindel, D.; Piggin, C. Evolution and adoption of conservation agriculture in the middle east. In Conservation Agriculture; Farooq, M., Siddique, K.H.M., Eds.; Springer Science: Berlin, Germany, 2015; pp. 197-224.

48. Yigezu, Y.A.; Mugera, A.; El-Shater, T.; Piggin, C.; Haddad, A.; Khalil, Y.; Loss, S. Explaining adoption and measuring impacts of conservation agriculture on productive efficiency, income, poverty and food security in Syria. In Conservation Agriculture; Springer Science: Berlin, Germany, 2015; pp. 225-247. [CrossRef]

(C) 2018 by the authors. Licensee MDPI, Basel, Switzerland. This article is an open access article distributed under the terms and conditions of the Creative Commons Attribution (CC BY) license (http:/ / creativecommons.org/licenses/by/4.0/). 